\title{
Diet Intake Pattern and Nutritional Status of Rural Population in Bangladesh
}

\author{
Md Monoarul Haque ${ }^{1+}$ \\ Md Amirul Hassan ${ }^{2}$ \\ Khaleda Islam ${ }^{3}$ \\ Md Rijwan Bhuiyan ${ }^{4}$ \\ Md Shah Jalalur Rahman Shahi \\ Rukshana Parvin Lipi ${ }^{6}$
}

'Department of Community Nutrition

Faculty of Public Health

Bangladesh University of Health Sciences (BUHS)

Dhaka, Bangladesh.

${ }^{2}$ Centre for Medical Education

DOHS, Mohakhali

Dhaka, Bangladesh.

${ }^{3}$ Institute of Nutrition \& Food Science

University of Dhaka

Dhaka, Bangladesh.

${ }^{4}$ Department of Public Health

Bangladesh University of Health Sciences (BUHS)

Dhaka, Bangladesh.

${ }^{5}$ Department of Immunology

Bangladesh University of Health Sciences (BUHS)

Dhaka, Bangladesh.

${ }^{6}$ Department of Public Health,

ASA University of Bangladesh (ASAUB)

Dhaka, Bangladesh.

\section{*Correspondence to:}

\section{Md Monoarul Haque}

Fellow

Department of Community Nutrition

Faculty of Public Health

Bangladesh University of Health Sciences (BUHS)

125/1, Darus Salam, Mirpur, Dhaka-1216, Bangladesh.

Mobile: +8801915839550

e-mail: monoarmunna@yahoo.com

\begin{abstract}
Objective: The aim of this study is to explore the diet intake pattern and nutritional status of rural population in Bangladesh. Methods: A population based crosssectional study was conducted in three rural villages of Mohespur Upazilla, Jhenaidah district, Bangladesh. Total 200 samples were collected purposively to conduct this study. Data were collected through personal face to face interview by structured and semi-structured questionnaire from the respondents. Results: The mean $( \pm \mathrm{SD})$ age of the respondents was $35 \pm 16.6$ years where $64 \%$ were male. The monthly dietary intake pattern of the respondents shows that majority of the respondents take pulses, fish, meat, egg, milk and fruits 1 to 2 time per month. Majority (94.5\%) of the respondents take cereals 2 to 3 times per day. In case of nutritional status, majorities (47\%) have normal nutritional status where $30 \%$ are overweight, $15 \%$ are obese and $8 \%$ are suffering from underweight. Study also shows that there is no relation between gender and nutritional status of the respondents. Conclusion: Finally, this study indicates that the overall dietary intake pattern of rural population in Bangladesh is poor. Further study should be needed in a large scale to explore the real scenario of dietary pattern and nutritional status of rural population in Bangladesh.
\end{abstract}

Key words: Diet pattern; nutritional status; rural area.

\section{INTRODUCTION}

Diets of populations around the world were primarily determined by the availability of local food and food practices. A balanced diet, adequate in all necessary nutrients; energy, protein, vitamins and minerals, can satisfy both perceptible and hidden hunger ${ }^{1}$. Cereals, largely rice, are the main food in Bangladesh. The typical rural diet in Bangladesh is, reportedly, not well balanced as well ${ }^{2}$.

Rural consumption of leafy and non-leafy vegetables has remained more or less the same over the past two decades after increasing over the preceding 30 years. Fruit consumption has declined in rural areas after more than doubling in the 1970s. With an average national per capita consumption of $23 \mathrm{~g}$ of leafy vegetables, $89 \mathrm{~g}$ of nonleafy vegetables and $14 \mathrm{~g}$ of fruit, the average Bangladeshi eats a total of $126 \mathrm{~g}$ of fruit and vegetables daily. This is far below the minimum daily consumption of 400 $\mathrm{g}$ of vegetables and fruit recommended by FAO and the World Health Organization $(\mathrm{WHO})^{3}$. Despite considerable improvement in the national rural health status, the nutritional well-being of rural people continues to be neglected. Children and women in Bangladesh suffer from high levels of malnutrition and micronutrient deficiencies such as low birth weight (LBW), undernutrition (underweight, stunting and wasting), vitamin A deficiency, iodine-deficiency disorders (IDD) and iron-deficiency anaemia (IDA). At the same time, new health problems related to over-nutrition such as obesity are emerging ${ }^{4}$. Maternal undernutrition (body mass index less than 18.5 $\mathrm{kg} / \mathrm{m} 2$ ) in non-pregnant women in the country, while declining from 54 percent in 1996-1997 to 38 percent in 2003, is still very high $^{5-6}$. 
Malnutrition early in life has long-lasting and negative effects on overall growth, morbidity, cognitive development, educational attainment and adult productivity ${ }^{7}$. The aim of this study is to explore the diet intake pattern and nutritional status of rural population in some village of Bangladesh.

\section{METHODS}

Study area and population

In March to September 2013 we conducted a population based cross-sectional study in some selected villages of Mohespur Upazilla in Jhenaidah district in Bangladesh where majority people lives on agriculture. People aged 19 years and above are considered the study population in this study.

Study design and sampling method

This was a population based cross-sectional study. We adopted a purposive sampling technique to select sample from each villages.

Sample size

200 samples were adopted purposively to conduct this study.

Tools

A structured and semi-structured questionnaire containing (i) socio-demographic and personal information; (ii) monthly dietary intake pattern; (iii) nutritional status of the respondents, was used in this study.

Data collection and data analysis

Data was collected by face to face interview from the respondents. Collected data was coded and entered in the computer and analyzed by using SPSS 15 software. Descriptive statistics were computed to describe both categorical and numerical variables. Inferential statistics were used to make relationship.

\section{RESULTS}

The mean age $( \pm$ SD) of the respondents $(n=200)$ were 35.34 $( \pm 16.59)$ years where $64 \%(128, n=200)$ respondents were male. The majorities (97.5\%) of the participants were Muslim and $80 \%$ were married. The educational level of the respondents were illiterate $(30 \%)$, primary $(11.5 \%)$, SSC $(42.5 \%)$, HSC (13.5\%), Graduate and above $(2.5 \%)$. The majority of the respondent's occupation were agriculture $(27.5 \%)$, than house wife $(26 \%)$ and service $(20.5 \%)$, Student $(11 \%)$, Business $(7.5 \%)$, others $(7.5 \%)$ respectively. The majority of the respondent's $(52.5 \%)$ monthly income was between 3000 to 5000 BDT. About $46 \%$ participants have family member upto 4 and $36 \%$ have family member more than 6 where $92 \%$ respondents lived in their own house. In case of fuel used in cooking, majority $(94.5 \%)$ use straw, 3\% use fire wood and $2.5 \%$ use others things. Among the respondents $92.5 \%$ use tube well as a source of drinking water and rest $(7.5 \%)$ of use tap water (Table 1). In case of Cereals intake $94.5 \%$ (189) respondents take 2 to 3 times per day. For pulse intake $34 \%$ respondents take 1 to 2 times per month and $33.5 \%$ 2 to 3 times per day, $22.5 \% 3$ to 6 times per week, $2.5 \% 1$ time per day respectively. For fish intake majority (49.5\%) of the respondents take 1 to 2 times per months and second majority (35\%) respondents take 2 to 3 times per day where $5.5 \%$ never take fish. In case of meat $97 \%$ respondents take 2 to 3 times per month and $3 \%$ take 3 to 6 times per week.
For egg intake pattern $71.5 \%$ respondents take 1 to 2 times per month and $18.5 \%$ take 3 to 6 time per week where $2.5 \%$ never take egg at all. For milk $64.5 \%$ respondents take 1 to 2 times per month and $14 \%$ take 1 time per day, $8.5 \%$ take 2 to 3 times per day, $8 \%$ take 3 to 6 time per week and 5\% never take milk. In case of vegetables intake $39 \%$ respondents take 3 to 6 times per day, $34 \%$ take 2 to 3 times per day, $14 \%$ take 1 time per day, $13 \%$ take 1 to 2 times per month. For fruit intake, 58\% respondents take 1 to 2 time per month, $20.5 \% 2$ to 3 times per day, $11.5 \% 1$ time per day and $10 \% 3$ to 6 times per week. For oil intake $100 \%$ respondents take 2 to 3 time per day. For stacks intake $65.5 \%$ respondents never take snacks at all where $14 \%$ take 1 time per day, 10 take 2 to 3 times per day, $8.5 \%$ take 1 to 2 time per month and rest of $3 \%$ take 3 to 6 time per week. Finally in sweets intake majority $(64.5 \%)$ respondents take 1 to 2 times per month and $19.5 \%$ take 3 to 6 time per week, $13.5 \%$ take 2 to 3 times per day where $2.5 \%$ never take sweets (Table 2). Among the respondents $47 \%$ have normal BMI where $30 \%$ were overweight, $15 \%$ were obese and rest of $8 \%$ was underweight (Figure 1). There is no significant relation $(\mathrm{P}=0.484)$ were found among gender and nutritional status of the respondents in $\mathrm{X}^{2}$ test from this study (Table 3).

Table 1: Socio-demographic characteristics of the study subjects $(n=200)$

\begin{tabular}{|c|c|}
\hline Variables & $\mathrm{n}(\%)$ \\
\hline Age $($ Mean \pm SD $)$ & $35.34 \pm 16.59$ \\
\hline \multicolumn{2}{|l|}{ Gender } \\
\hline Male & $128(64)$ \\
\hline Female & $72(36)$ \\
\hline \multicolumn{2}{|l|}{ Religion } \\
\hline Muslim & $195(97.5)$ \\
\hline Hindu & $5(2.5)$ \\
\hline \multicolumn{2}{|l|}{ Educational level } \\
\hline Illiterate & $60(30)$ \\
\hline Primary & $23(11.5)$ \\
\hline $\mathrm{SSC}$ & $85(42.5)$ \\
\hline $\mathrm{HSC}$ & $27(13.5)$ \\
\hline Graduate and above & $5(2.5)$ \\
\hline \multicolumn{2}{|l|}{ Occupation } \\
\hline Agriculture & $55(27.5)$ \\
\hline Service & $41(20.5)$ \\
\hline Business & $15(7.5)$ \\
\hline Housewife & $52(26)$ \\
\hline Student & $22(11)$ \\
\hline Others & $15(7.5)$ \\
\hline \multicolumn{2}{|c|}{ Monthly Family Income (BDT)* } \\
\hline$<3000$ & $30(15)$ \\
\hline $3000-5000$ & $105(52.5)$ \\
\hline $5000-10000$ & $59(29.5)$ \\
\hline $10000-15000$ & $6(3.0)$ \\
\hline \multicolumn{2}{|l|}{ Marital Status } \\
\hline Married & $161(80)$ \\
\hline Unmarried & $39(19.5)$ \\
\hline \multicolumn{2}{|l|}{ Household Member } \\
\hline Upto 4 & $92(46)$ \\
\hline $5-6$ & $36(18)$ \\
\hline$>6$ & $72(36)$ \\
\hline \multicolumn{2}{|l|}{ Housing Status } \\
\hline Own House & $184(92)$ \\
\hline Rent / Others & $16(8)$ \\
\hline \multicolumn{2}{|l|}{ Housing Condition } \\
\hline Tin Wall Tin Roof & $20(10)$ \\
\hline Timber & $5(2.5)$ \\
\hline Timber Wall Tin Roof & $28(14)$ \\
\hline Bamboo Wall Tin Roof & $147(73.5)$ \\
\hline \multicolumn{2}{|l|}{ Fuel Used in Cooking } \\
\hline Fire Wood & $6(3)$ \\
\hline Straw & $189(94.5)$ \\
\hline Others & $5(2.5)$ \\
\hline \multicolumn{2}{|l|}{ Source of Drinking Water } \\
\hline Tube well & $185(92.5)$ \\
\hline Tap & 7.5 \\
\hline
\end{tabular}

The result is expressed as number $(\%)$ and mean $\pm \mathrm{SD}) ;{ }^{*} \mathrm{BDT}=$ Bangladeshi Taka. 
Table 2: Monthly dietary intake pattern of respondents $(n=200)$

$\begin{array}{lccccc}\text { Food Items } & \begin{array}{c}2-3 \text { tims/day } \\ n(\%)\end{array} & \begin{array}{c}1 \text { tims/day } \\ n(\%)\end{array} & \begin{array}{c}3-6 \text { times/wk } \\ n(\%)\end{array} & \begin{array}{c}1-2 \text { tims/mnth } \\ n(\%)\end{array} & \begin{array}{c}\text { Never } \\ n(\%)\end{array} \\ \text { Cereals } & 189(94.5) & 6(3) & 5(2.5) & 0(0) & 0(0) \\ \text { Pulses } & 67(33.5) & 5(2.5) & 45(22.5) & 68(34) & 0(0) \\ \text { Fish } & 70(35) & 20(10) & 32(16) & 99(49.5) & 11(5.5) \\ \text { Meat } & 0(0) & 0(0) & 6(3) & 194(97) & 0(0) \\ \text { Egg } & 5(2.5) & 10(5) & 37(18.5) & 143(71.5) & 5(2.5) \\ \text { Milk } & 17(8.5) & 28(14) & 16(8) & 129(64.5) & 10(5) \\ \text { Vegetables } & 68(34) & 28(14) & 78(39) & 26(13) & 0(0) \\ \text { Fruits } & 41(20.5) & 23(11.5) & 20(10) & 116(58) & 0(0) \\ \text { Oil } & 200(100) & 0(0) & 0(0) & 0(0) & 0(0) \\ \text { Snacks } & 20(10) & 28(14) & 6(3) & 17(8.5) & 129(65.5) \\ \text { Sweets } & 27(13.5) & 1(.5) & 39(19.5) & 128(64.5) & 5(2.5)\end{array}$

Results were expressed as number \%

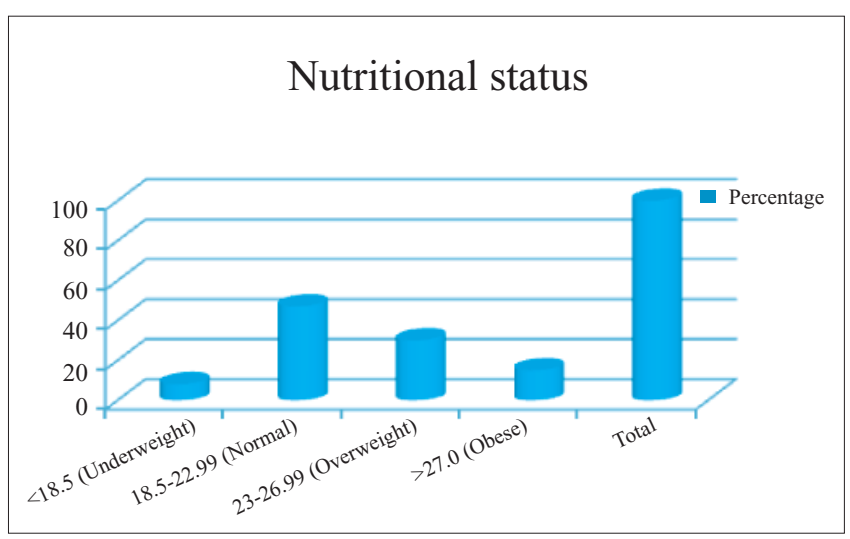

Figure 1: Nutritional status of respondents $(n=200)$
Table 3: Relationship between gender and nutritional status of the study subjects $(n=200)$

\begin{tabular}{lcccc} 
BMI & Male & Female & $\chi^{2}$ & Pvalue \\
$<18.5$ (Underweight) & $8(4)$ & $8(4)$ & 2.433 & 0.484 \\
$18.5-22.99$ (Normal) & $63(31)$ & $31(16)$ & & \\
$23.0-26.99$ (Overweight) & $38(19)$ & $22(11)$ & & \\
$>27.0$ (Obese) & $20(10)$ & $10(5)$ & & \\
Total & $128(64)$ & $72(36)$ & & \\
\hline
\end{tabular}

Results were expressed as number $\%, \chi^{2}$ test was performed and $\mathrm{P}<0.05$ was level of significance

\section{DISCUSSION}

Promoting healthy diets and lifestyles to reduce the global burden of non-communicable diseases requires a multi-sectoral approach involving the various relevant sectors in societies. Research evidence from developing countries shows that household food insecurity is closely related to the under nutrition $^{8-9}$. Based on the results of the study, it appears that intake of fish, meat, egg, milk and fruits are very poor among the respondents. The reason of this condition can be poverty and lack of education ${ }^{10-12}$. In case of nutritional status although $47 \%$ respondents have normal BMI but $30 \%$ respondents have overweight and $15 \%$ are obese. Findings show that, now a day's obesity is increasing day by day in rural community as well as emerging in developing counties ${ }^{13}$. Study found there is no relation between gender and nutritional status, although the scenario is different. Study found women in rural area are suffering from severe mal nutrition ${ }^{8-9}$.

\section{CONCLUSION}

Finally we can say from this study that the overall dietary intake pattern of rural people in Bangladesh is poor. Further study is needed in large scale and details way to find out specific dietary intake patterns and as well as their nutritional status of rural people in Bangladesh.

\section{DISCLOSURE}

All the authors declared no competing interest. 


\section{REFERENCES}

1. Jahan, K. \& Hossain, M. 1998. Nature and extent of malnutrition in Bangladesh, Bangladesh National Nutrition Survey, 1995-1998. Dhaka, Institute of Nutrition and Food Science, Dhaka University, Bangladesh.

2. Bangladesh National Nutrition Survey (1995-1996).

3. FAO/WHO. 2003. Diet, nutrition and the prevention of chronic diseases. Report of a joint FAO/WHO. Expert Consultation. WHO Technical Report Series 916. Geneva. World Health Organization.

4. World Bank. 2005. Maintaining Momentum to 2015: An impact evaluation of interventions to improve maternal and child health and nutrition in Bangladesh. Washington, The World Bank.

5. Bangladesh Demographic and Health Survey, 2000.

6. Helen Keller International/IPHN, 2004.

7. FAO. (2002). World agriculture towards 2015/2030.

8. J. Harrington1, et.al. : Food poverty and dietary quality: is there a relationship, J Epidemiol Community Health 2009; 63:16.

9. James A. Levine, 2011, Poverty and Obesity in the U.S. (Accessed on November 13 2013), $<\mathrm{http}: / /$ diabetes.diabetesjournals.org/content/60/11/2667.full.pdf $+\mathrm{html}>$.

10. Clin J, Nutr, A, Poverty and obesity: the role of energy density and energy costs, American Society for Clinical Nutrition, 2004;79(1):6-16.

11. Patterson PD, et.al. Obesity and physical inactivity in rural, America. J Rural Health. 2004; 20(2):151-159.

12. Hoffman, DJ, 2012, Food corporate document repository: Agriculture and Consumer Protection, Obesity in developing countries: causes and implications, (Accessed on December 20 2013), $<\mathrm{http}: / / w w w . f a o . o r g / d o c r e p / 003 / y 0600 \mathrm{~m} / \mathrm{y} 0600 \mathrm{~m} 05 . \mathrm{htm}>$.

13. Prentice1, AM: The emerging epidemic of obesity in developing countries, International Journal of Epidemiology, 2006; 35:93-99. 